\title{
GAZDASÁGI FOLYAMATOK MAGYARORSZÁGON 2019-2020 FORDULÓJÁN
}

\author{
DR. BELYÓ PÁL, főiskolai tanár \\ EDUTUS Egyetem \\ belyo.pal@edutus.hu
}

DOI $\underline{10.47273 / A P .2020 .20 .5-25}$

\begin{abstract}
ABSZTRAKT
A magyar gazdaság már 2019-ben a korábbi évekhez viszonyítva kissé lassabban bővült. Az év végére az építöipar növekedése lassult, és az iparág növekedési várakozásai jelentősen gyengültek. Az egyensúly romlásának másik tünete az volt, hogy a fogyasztói áremelkedés üteme enyhén felgyorsult, és a forint tovább gyengült. A vállalatok és a háztartások optimizmusa is csökkent, részben a külső gazdaságok lassulását okozó kockázati tényezők - a Brexit, a globális gazdasági helyzet észrevehető romlása, és ezáltal a külkereskedelmi partnereink növekedésének lassulása - részben a hazai munkaerö-piaci anomáliák miatt, amelyeket a régóta fennálló hazai versenyképességi problémák alapoztak meg. A kormány korábbi gazdasági tervei szerint a magyar GDP 4,9 százalékos növekedése 1,5-2 százalékponttal csökken 2020-ban. A 2019 évi prognózis szerint az építőipar jelentős csökkenése, az ipari termelés mérsékeltebb csökkenése és a beruházások jelentős gyengülése mellett a fogyasztás a jövedelmi feltételek romlása miatt is várhatóan csökken. A járvány természetesen alaposan megváltoztatta a terveket is.
\end{abstract}

\begin{abstract}
The Hungarian economy has already expanded slightly slower in 2019 compared to previous years. By the end of the year, construction growth had slowed and the industry's growth expectations had weakened significantly. Another symptom of a deterioration in the balance was that the pace of consumer price increases accelerated slightly and the forint continued to weaken. Optimism among companies and households has also diminished, partly due to the risk factors that have caused the slowdown in external economies - Brexit, the noticeable deterioration of the global economic situation and thus the slowdown in the growth of our external trade partners - partly due to domestic labour market anomalies, which have been the basis of long-standing domestic competitiveness problems. According to the government's previous economic plans, hungarian GDP growth of 4.9 percent will decrease by 1.5-2 percentage points in 2020. In addition to the projections for 2019, consumption is also expected to decrease due to a significant decrease in construction, a more moderate decline in industrial production and a significant weakening of investment. The epidemic, of course, has changed the plans thoroughly.
\end{abstract}




\section{Világgazdasági folyamatok az évtized végén}

2019-ben a globális gazdaság az előzetes adatok szerint csökkenő dinamikával bővült. A Nemzetközi Valutaalap szerint a növekedés korábban, 2018-ban 3,6\%-ot ért el, ami még csak 0,1 százalékponttal maradt el az előző évitől. 2019-ben viszont az eddig ismert adatok szerint a bruttó hazai termék - jelentős lassulással - 3\%-ra csökkent. A politikai kockázatok, a regionális konfliktusok hatására az idei kilátások kedvezőtlenebbek a korábban feltételezettnél. Az eddigi adatok szerint a fejlett országok gazdaságában mérséklődött a fejlődés dinamikája, a 2017. évi és a 2018. évi 2,3\%-ot követően 2019-ben 1,7\%-kal nőtt a bruttó hazai termékük. Az IMF szakértői 2020-ra is 1,7\%-os GDP emelkedést vártak. Az Amerikai Egyesült Államok gazdaságában jelenleg még a fejlett országok átlagánál nagyobb mértékü a növekedés: 2019ben becsült adatok alapján 2,4\%-kal emelkedett a bruttó hazai termék. Az idei prognózis további lassulással, 2,1\%-os bővüléssel számolt. A japán gazdaságban a hosszú ideig tartó stagnálást némi fellendülés követte. Az elmúlt két évben 0,8\%-os, illetve 0,9\%-os növekedést mértek, míg 2020-ban a tavalyit el nem érve, a bruttó hazai termék volumenében 0,5\%-os emelkedést várnak . Kanadában a múlt évben lassult a gazdaságnövekedés dinamikája. 2018ban 1,9\%-kal, 2019-ben 1,5\%-kal nőtt a GDP, amit idén várhatóan 1,8\%-os emelkedés követ. A fejlődő országok gazdasági növekedése szintén lassult 2019-ben. A 2017. évi 4,7\%-os, 2018. évi 4,5\%-os dinamikát már csupán 3,9\%-os növekedés követte 2019-ben. Az idei évre viszont 4,6\%-os GDP gyorsulást becsült az IMF.

A világkereskedelmet a kínai növekedési ütem mérséklődése jelentősen befolyásolja. A korábban több alkalommal is jelzett változás már 2017-ben bekövetkezett 6,9\%-ra lassulással. 2018-ban 6,6\%-kal, 2019-ben pedig csupán 6,1\%-kal emelkedett a bruttó hazai termék volumene. 2020-ra - még a válság előtt - további lassulást, 5,8\%-ot vártak az elemzők. India gazdaságának bővülése két évvel ezelőtt már meghaladta Kínáét, azaz 2017-ben 6,7\%-kal, 2018-ban 6,8\%-kal, 2019-ben további 6,1\%-os lassulással bővült az indiai gazdaság, míg 2020ra 7\%-os gyorsulást prognosztizáltak. Oroszországban három éve megtört a recesszió, a-a megelőző évek 3,7\%-os, illetve 0,2\%-os zsugorodását 2017-ben 1,5\%-os, 2018-ban 2,3\%-os GDP emelkedés váltotta. 2019-ben csak 1,1\%-kal nőtt a GDP, míg 2020-ra kis gyorsulást, 1,9\%-os bővülést vártak. Brazília az öt évvel ezelőtti komoly visszaesést jelentő recesszión túljutott, 2017-ben 1\%-kal, majd 1,1\%-kal, míg 2019-ben 0,9\%-kal nőtt a GDP. 2020-ra itt is komolyabb, 2\%-os teljesítménybővülést vártak. Fülöp-szigetek, Indonézia, Malajzia, Thaiföld 
és Vietnam gazdasága kiemelkedő ütemben teljesít, az 5,3\%-os, 5,2\%-os gazdaságnövekedést 2019-ben 4,8\%-os bővülés követte, és ezt remélték 2020-ban is 4,9\%-os dinamikával.

A legnépesebb afrikai országban, Nigériában a bruttó hazai termék korábbi kiemelkedő üteme 2016-tól 1,6\%-kal visszaesett, majd 2017-ben szerény ütemben, 0,8\%-kal, 2018-ban 1,9\%-kal, míg 2019-ben 2,3\%-kal emelkedett. 2020-ra 2,5\%-os bővülést jeleztek. Mexikóban is szerényebb a növekedési ütem a fejlődő országok átlagához képest, így az előző két év 2- 2\%os bővülését követően 2019-ben 0,4\%-os volt a GDP növekedésł, ez évre erőteljesebb, 1,3\%os bővülésre várt az IMF.

\section{Európai tendenciák}

Az eurózónában három évvel ezelött következett be ütemváltás: a 2014. évi 1,3\%-os bővülést 2015-ben 2,1\%-os, míg 2016-ban 1,8\%-os emelkedés követte, amely után a 2017-ben 2,4\%kal, míg 2018-ban 1,9\%-kal nött a GDP. 2019-ben ismét csökkent a növekedés, - az Eurostat szerint $-1,2 \%$ volt a bővülés. Az IMF a továbbiakban is szerény ütemü fejlődést jósol, azaz 2020-ra 1,4\%-os növekedést prognosztizálnak. A nem túl kedvező várakozást az eurózóna három vezető gazdaságának valószínüsített fejlődése határozza meg. A német gazdaságban a két évvel ezelőtti 1,5\%-os GDP most 2019-ben csupán 0,5\%-kal emelkedett, melyet várhatóan 1,2\%-os növekedés követhetett volna. Franciaországban négy éve még stagnálás közeli állapotban volt a gazdaság; ezt követően 2018-ban a GDP 1,7\%-kal, míg 2019-ben 1,2\%-kal emelkedett. Olaszországban ennél szerényebb volt a növekedés dinamikája. A 2017-es 1,7\%os zsugorodás után 2018-ban 0,9\%-os bővülés, 2019-ben stagnálás következett, és 2020-ra még a válság elött - mindössze $0,5 \%$-os növekedést vártak. Spanyolországban - a korábbi recessziót követően - 2017-ben 3\%-os, 2018-ban 2,6\%-os, 2019-ben pedig 2,2\%-os volt a növekedés. 2020-ban még a kedvező, 1,8\%-os várható GDP bővülésük meghaladhatta volna az eurózóna átlagát.

A nem eurózónabeli uniós tagállamok gazdasági teljesítménye kissé jobb volt a közös valutaövezet növekedési üteménél. Az Európai Unió egészének gazdasága 2017-ben 2,7\%-kal, 2018-ban 2,2\%-kal, míg 2019-ben 1,4\%-kal bővült. 2020-ra 1,6\%-os emelkedést vártak az Európai Unió egyesített GDP volumenére. Az előző években a bővülésben jelentős szerepe volt a brit gazdaságnak: a korábbi 3\% feletti dinamikát - a Brexit feltehető következményeként tavalyelött 1,4\%-os, míg 2019-ben 1,2\%-os növekedés követte. Ez évre pedig - már Európai Unión kívüli államként - a gazdasági növekedését 1,4\%-osra tervezték. A kelet-közép-európai 
térség országainak GDP volumenindexe a válság előtti várakozások szerint 2,5 és 3,5\% között volt.

\section{A magyarországi gazdasági folyamatok jellemzői}

\section{A makrogazdaság fejlödése}

A magyar gazdaság 2019-ben kiemelkedő dinamikával bővült. A 2016. évi szerényebb, 2,1\%os ütemet követően a következő évben már érzékelhető volt a 2014-2020. évek középtávú uniós ciklusában - sajátos módon - lehívott jelentős források élénkítő hatása. Ennek megfelelően 2017-ben 4,5\%-kal, 2018-ban 5,1\%-kal emelkedett a bruttó hazai termék volumene. 2019 első negyedévében - szezonálisan és naptárhatással kiigazított adatok alapján - 1,4\%-kal nőtt a GDP az előző negyedévhez, és 5,2\%-kal a megelőző év azonos időszakához viszonyítva. A második negyedévben némileg csökkent a dinamika: a bruttó hazai termék - szezonálisan és naptárhatással kiigazított adatok alapján - 1,1\%-kal emelkedett az előző negyedévhez, és 5,2\%kal az egy évvel korábbihoz viszonyítva. A harmadik negyedévben - a várakozásokhoz képest - némileg nagyobb volt a dinamika: a GDP - ugyanezen összevetésben vizsgálva - 1,1\%-kal nőtt az előző negyedévhez, és 4,8\%-kal az elöző év azonos időszakához képest. Az első háromnegyed évben - szezonálisan és naptárhatással kiigazított adatok alapján - 5\%-kal emelkedett a bruttó hazai termék volumene. A negyedik negyedévben az előző negyedévhez képest, szezonálisan és naptárhatással kiigazított és kiegyensúlyozott adatok alapján:

A gazdaság teljesítménye 1,0\%-kal nőtt,

$\square$ A termelési oldalon a szolgáltatások bruttó hozzáadott értéke 1,5\%-kal bővült, az iparé 1,1, az építöiparé 1,4\%-kal csökkent,

A felhasználási oldalon a végső fogyasztás összetevői közül a háztartások fogyasztási kiadása 1,4, a közösségi fogyasztás 1,2, a kormányzattól származó természetbeni társadalmi juttatások volumene 0,5\%-kal lett nagyobb. A bruttó állóeszköz-felhalmozás 0,3\%-kal emelkedett. A külkereskedelemben az export 1,5\%-kal, az import 1,4\%-kal csökkent.

2019-ben a hazai GDP értéke folyó áron 46.787 milliárd forint volt, és a volumene az előző évhez képest 4,9\%-kal bővült. A szezonálisan és naptárhatással kiigazított és kiegyensúlyozott adatok alapján is 4,9\%-kal emelkedett a gazdaság teljesítménye. 
$\square$ A termelési oldalon az építőipar hozzáadott értéke kiemelkedően, 21\%-kal, az iparé 5,0-kal, a szolgáltatásoké 4,2\%-kal nőtt, a mezőgazdaságé 0,3\%-kal csökkent.

A GDP bővüléséhez a szolgáltatások 2,3 százalékponttal, míg az ipar 1,0 és az építőipar 1,0 százalékponttal járult hozzá.

$\square$ A felhasználási oldalon a háztartások tényleges fogyasztása 4,4, a közösségi fogyasztás 2,0\%-kal nőtt, ezek együttes eredményeként a végső fogyasztás 4,1\%kal magasabb lett. A bruttó felhalmozás 9,5, ezen belül a bruttó állóeszközfelhalmozás 15\%-kal emelkedett. Az export 6,0, az import 6,9\%-kal bővült.

A felhasználási oldalon a végső fogyasztás 2,8, a bruttó felhalmozás 2,6 százalékponttal emelte a GDP növekedési ütemét. A külkereskedelmi forgalom egyenlege összességében 0,4 százalékponttal lassította a gazdasági teljesítmény bővülését.

2019 egészében - a megelőző évinél magasabb ütemű - az 5\%-ot közelítő volumenindex több mint 3,5 százalékponttal meghaladta az Európai Unió, valamint az eurózóna átlagát, és a térségünkben is kiemelkedő növekedést jelent. A felfutás időszakában kiépített kapacitások folyamatos és közel egyenletes hasznosítása azonban bizonytalannak látszanak. Feltételezhetö, hogy kihasználatlanná, feleslegessé válnak, nem képesek megteremteni akár a technológia megvásárlásának, akár a szakmai ismeretek továbbfejlesztésének forrását. A rendelkezésre álló adatok arra utalhattak már az év elején, hogy a gazdasági növekedés elérte a csúcspontját, és 2020-ban csak a 3\%-ot éppen meghaladó növekedésre lehet számítani.

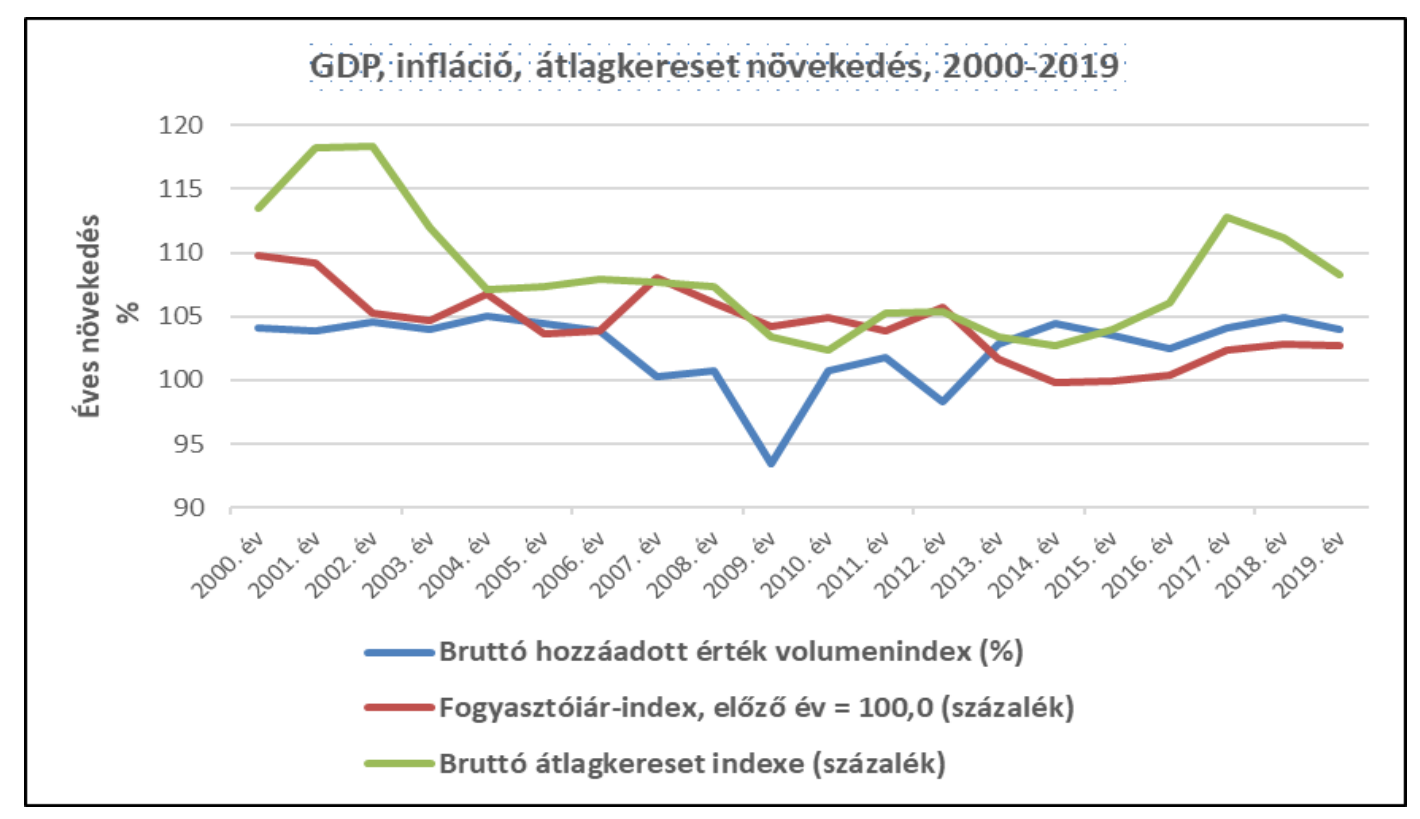

Forrás: KSH, saját számítás 
A válság okozta gazdasági visszaesés azonban már elkerülhetetlen. Ez tovább erősítheti azt a veszélyt, hogy a magyar gazdasági növekedés gyorsulása megszakad, és még növekedhet is a leszakadásunk mértéke. A magyar gazdaság felzárkózásának legfontosabb feltétele a modern technológia alkalmazása, az együtthaladás a globális gazdaság fejlődésével. Egyik nagy gondunk a gyenge versenyképességünk, az utóbbi évtizedben a világ versenyképességi rangsorában érzékelhetően hátrább kerültünk.

\section{A külgazdasági helyzet}

2019-ben a külkereskedelmi forgalom tendenciaszerüen lassult. A termék- külkereskedelmi mérleg többlete 665 millió euróval csökkent, 4,9 milliárd eurót tett ki. A kivitel értéke 108,9 milliárd euróra (35,4 ezer milliárd forint), a behozatalé 104,1 milliárd euróra (33,8 ezer milliárd forint) teljesült. 2018-hoz viszonyítva a kivitel volumene 4,2, a behozatalé 5,7\%kal emelkedett.

A külkereskedelmi termékforgalom forintban mért árszínvonala a behozatalban 1,1, a kivitelben 1,7\%-kal volt nagyobb az előző év azonos időszakánál. A cserearány így 0,6\%-kal javult. Ebben szerepet játszott, hogy a forint árfolyama az euróhoz képest 2,0, a dollárhoz viszonyítva 7,5\%-kal leértékelődött.

A külkereskedelmi termékforgalom alakulása, 2019

\begin{tabular}{|c|c|c|c|c|c|c|}
\hline \multirow{2}{*}{ Megnevezés } & \multicolumn{2}{|c|}{ Export } & \multicolumn{2}{c|}{ Import } & \multicolumn{2}{c|}{ Egyenleg } \\
\cline { 2 - 7 } & $\begin{array}{c}\text { érték, } \\
\text { folyó } \\
\text { áron }\end{array}$ & $\begin{array}{c}\text { elózó év } \\
100\end{array}$ & $\begin{array}{c}\text { érték, folyó } \\
\text { áron }\end{array}$ & $\begin{array}{c}\text { az előzó év } \\
=100\end{array}$ & $\begin{array}{c}\text { érték, folyó } \\
\text { áron }\end{array}$ & $\begin{array}{c}\text { az előzó év } \\
\text { azonos } \\
\text { időszakában }\end{array}$ \\
\hline Milliárd forint & 35416 & 106 & 33833 & 106,9 & 1583 & 1752 \\
\hline Millió euró & 108929 & 103,9 & 104074 & 104,8 & 4855 & 5520 \\
\hline
\end{tabular}

2019. év végére egy év alatt a kivitel volumene 0,5\%-kal mérséklődött, a behozatalé 4,3\%-kal emelkedett. Az aktívum 114 millió euró volt, az egyenleg 267 millió euróval romlott. Az eltérő naptárhatást figyelembe véve a behozatal 1,7\%-kal nőtt, míg a kivitel volumene 4,1\%-kal visszaesett. A termék-külkereskedelmi mérleg-többlet 4,9 milliárd euróra teljesült, ez 665 millió euróval kevesebb, mint az előző évben. 
Az év utolsó hónapjában bonyolódó külkereskedelmünkben a kivitelünk 7,5 milliárd euró (2499 milliárd forint), a behozatalé 7,4 milliárd euró (2462 milliárd forint) volt. Ez az éves átlaghoz viszonyítva a behozatalban kisebb, a kivitelben kissé erőteljesebb változás volt, azaz euróban az export értéke 1,3\%-kal csökkent, az importé 2,3\%-kal nőtt.

Említésre méltó, hogy az exportunk 2019. IV. negyedévi értéke 6,6 milliárd euró (2,2 ezer milliárd forint), az importé 4,7 milliárd euró (1,6 ezer milliárd forint) volt. Kereskedelmi többletünk az európai uniós forgalomban nőtt, az EU-n kívüli országok esetében az aktívumunk - leginkább az ázsiai országokkal, azon belül is a Japánnal folytatott kereskedelem kis szükülése következtében - csökkent. A többlet az amerikai és az EU-n kívüli európai országokkal folytatott kereskedelemben is kissé visszaesett.

Ezen belül az év utolsó hónapjában a gépek és szállítóeszközök (2018. decemberi áron számított) exportja 1,9\%, importja 0,1\%-kal emelkedett. Ezen belül a közúti jármüvek személygépkocsik és az autóbuszok - exportja kismértékben nőtt, míg importja pár százalékkal visszaesett, amely a gépjármüalkatrészek és a személygépkocsik forgalomváltozásával függ össze. A híradástechnikai, hangrögzítő és -lejátszó készülékek exportja kissé visszaesett, de behozataluk mintegy 25\%-kal emelkedett. Ezt a növekedést a rádióhullámú készülék alkatrészeinek, a vezetékes távbeszélő készülékeknek, a videótelefonok és alkatrészeinek, míg a csökkenést a TV-készülékek, valamint a rádióhullám elvén müködő készülékek alkatrészeinek forgalomváltozása okozta. A villamos gép, készülék és műszer exportja jelentősen nőtt, mintegy 15\%-kal, behozataluk is kismértékben emelkedett. A növekedés az elektromos akkumulátor és alkatrészeinek, valamint az elektromos transzformátor és alkatrészeinek exportja eredményezte, az importban pedig az elektronikus integrált áramkör forgalma nőtt. Az energiafejlesztő gép és berendezés export mintegy 13\%-kal, e termékcsoportban az import 2-3\%-kal maradt az előző évitöl. A csökkenést az exportban a belső égésű motorok, a dízelmotorok, az importban a belső égésű motorok alkatrészeinek forgalomváltozása befolyásolta.

A feldolgozott termékek export-teljesítménye 3,8\%-kal csökkent, importja 4,4\%-kal emelkedett. Az energiahordozók exportja - így a természetes és mesterséges gáz, illetve a villamos energia kivitel - 15\%-kal visszaesett, importjában pedig a kőolaj és kőolajtermékek volumene 24\%-kal nőtt. Az élelmiszerek, italok, dohányáruk exportja 2,9, importja 7,5\%-kal növekedett. E változásokon belül fontos tényező a hús és húskészítmények, ezen kívül a behozatalban a zöldségféle és gyümölcs forgalomváltozása. Említésre méltó, hogy az EU-n 
kívüli országokba irányuló kivitelünk volumene 11\%-kal, a behozatalunké 10\%-kal nőtt, és az egyenleg e relációban - bár 263 millió eurós volt a passzívum - 61 millió eurós javulást eredményezett.

A szolgáltatás-külkereskedelmünk többlete 2019 utolsó negyedévében 1,9 milliárd eurót (647 milliárd forintot) ért el. Ennek az aktívumunknak pedig 46\%-a turizmusból, 35\%-a pedig a szállítási szolgáltatásokból származott. A szolgáltatásexportunk értéke 2019. IV. negyedévi forgalma 2018-hoz viszonyítva-euróban számítva 3,8 (forintban 6,7), az importé 6,8\%-kal (forintban 9,8 \%-kal) bővült. Az egyenleg kedvezőtlenebbé válása leginkább a bérmunka szolgáltatási díjak és az üzleti szolgáltatások mérlegromlásával magyarázható.

Szolgáltatásexportunk 72\%-át, szolgáltatás-importunk 77\%-át az Európai Unió tagországaival bonyolítottuk le, ebben a viszonylatban 1,2 milliárd eurós többlet keletkezett.

Legfontosabb partnerünkkel, Németországgal az összforgalom 20\%-át bonyolítottuk. A második legfontosabb Egyesült Államok 9, a harmadik helyen álló Ausztria 8\%-os arányban részesedett a kereskedelemböl.

A teljes szolgáltatásexportból az üzleti szolgáltatások csoportjának 45\%-os (ezen belül az egyéb üzleti szolgáltatásoknak 24\%-os) volt a részesedése, ezt követte a szállítási szolgáltatások $25 \%$, majd a turizmus $22 \%$-kal. Import tekintetében is ugyanezen szolgáltatáscsoportok voltak a dominánsak. A legkiemelkedőbb az üzleti szolgáltatások részesedése volt 61\%-kal (ezen belül az egyéb üzleti szolgáltatásoké 37\%), a szállítási szolgáltatások 21, a turizmus 11\%-kal részesedett a teljes importforgalomból.

\section{A beruházások alakulása}

A nemzetgazdasági beruházások volumene 2019-ben az előző évhez képest 14\%-kal bővült. Számottevő mérséklődés ezen belül az építési beruházásoké 16\%-osra, és a gép- és berendezésberuházások 11\%-osra mérséklődő növekedése.

A legalább 50 föt foglalkoztató vállalkozások körében - amelyek a beruházásokból mintegy 15\%-kal részesednek - $20 \%$-kal, a költségvetési szerveknél pedig 11\%-kal nőtt a beruházások teljesítménye. A legjelentősebb beruházó ágak közül a teljesítményérték több mint negyedét realizáló feldolgozóiparban 16\%-kal, az ingatlanügyletek körében 17\%-kal, a szállítás, raktározásban 15\%-kal növekedtek a beruházások, ezek az ágazatok az összes volumenből több mint $25 \%$-kal részesednek. 
Az előző évhez viszonyítva a bővülés, fejlesztések a legnagyobb mértékben a kis súlyú víz- és hulladékgazdálkodásban történtek (39\%), de jelentős volt a növekedés a müvészet, szórakoztatás, szabadidő nemzetgazdasági ágban (33\%), és a szálláshely-szolgáltatás, vendéglátás ágazataiban is $(32 \%)$. Az információ, kommunikáció és az oktatás területén azonban 2018-hoz képest alacsonyabb volt a teljesítmény.

Az év utolsó negyedévében a nemzetgazdasági beruházások 5,9\%-kal bővültek. Említést érdemel a jármügyártás - szélesebben a nagysúlyú feldolgozóipar - beruházásainak mérséklődése. A szolgáltatási ágak többségében a beruházások a nemzetgazdasági átlag felett nőttek. A beruházási tevékenység negyedik negyedéves 5,9\%-os bővülésén belül a teljesítményérték több, mint hattizedét képviselő építési beruházásoké 8,9\%-kal, a mintegy négytizedét kitevő gép- és berendezés-beruházásoké 1,6\%-kal nőtt. Elmaradt jelentősen a korábbi időszakokétól az építési, és a gépberuházások növekedési üteme is.

Az 50 főnél nagyobb vállalkozásoknál a fejlesztések a korábbi időszakok átlagához képest kisebb mértékben, 5,6\%-kal nőttek. A beruházások 16\%-át megvalósító költségvetési szerveknél azonban a megelőző negyedévi stagnálást követően 9,9\%-kal bővült a volumen.

A feldolgozóipari fejlesztések a tárgynegyedévben 5,5\%-kal estek vissza, kiemelkedő mértékben mérséklődött a jármügyártás, de csökkent az alágak többségének növekedése, így az élelmiszeriparé is. A több éve folyó, nagy értékű projektekkel kiemelkedő volt a bővülés a villamos berendezés és a gép-, gépi berendezések alágazatában. 
A nemzetgazdasági beruházások teljesítményértéke*

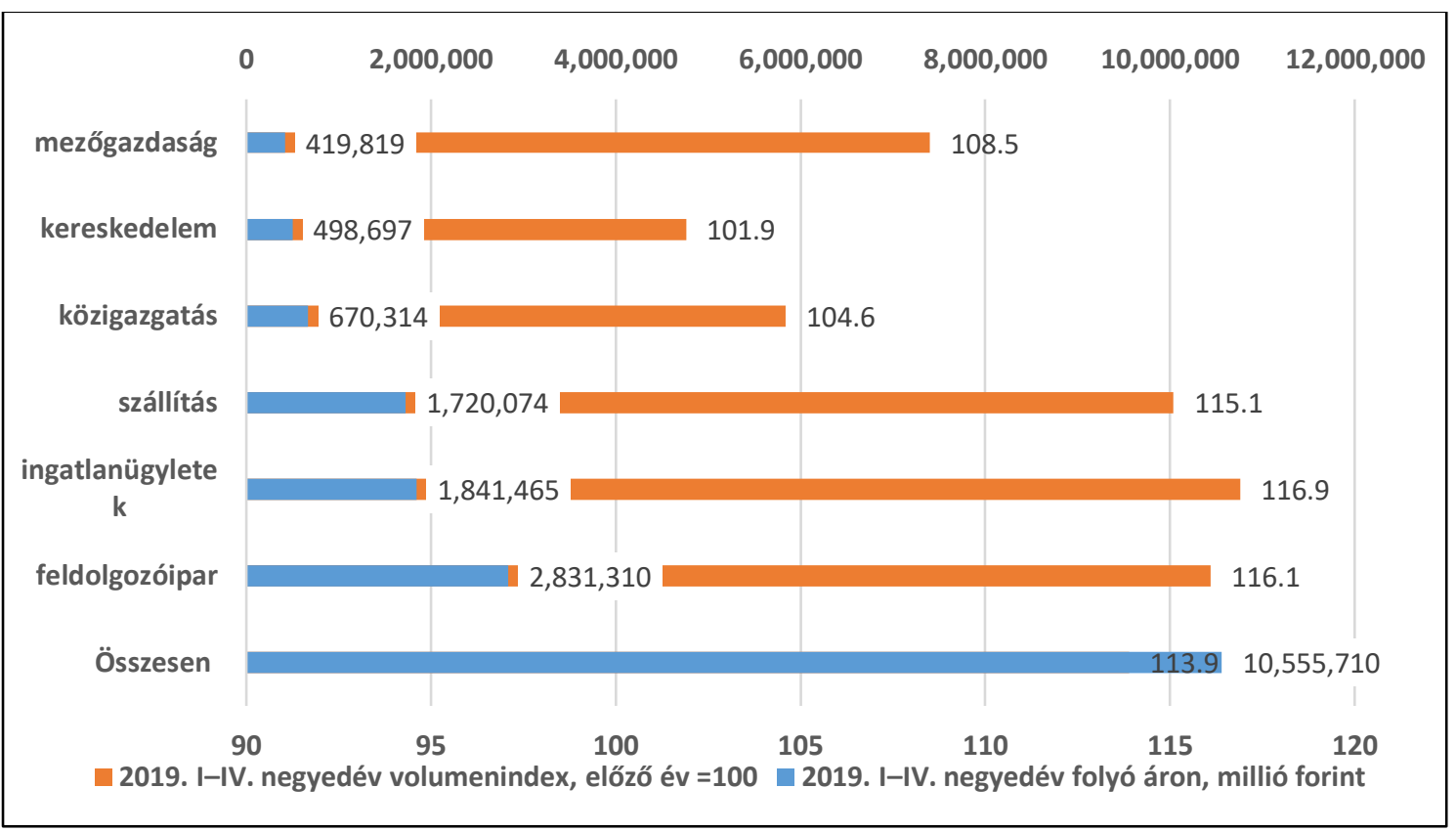

Forrás: KSH, saját számítás

* Az egész évi beruházási teljesítmény alapján a hat legnagyobb súlyú nemzetgazdasági ág adatai

A nemzetgazdasági ágak nagy részében emelkedett a beruházási aktivitás. A nemzetgazdasági beruházások 20\%-át kitevő, így a második legnagyobb beruházónak tekinthető ingatlanügyletek területén 16\%-kal emelkedett a beruházások teljesítménye. E csoporton belül a lakásépítések jelentős bővülése mellett a szolgáltató üzleti létesítményekben bevásárlóközpontok, logisztikai csarnokok - elvégzett beruházások is kiugróan növekedtek.

A kisebb súlyú nemzetgazdasági ágakban is érezhetően meglódultak a fejlesztések, az energiaipari fejlesztések 22\%-os bővülését az atomenergiával kapcsolatos nagyberuházások eredményezték. A szálláshely-szolgáltatás, vendéglátás területén 14\%-os növekedést eredményeztek a folytatódó szálloda-felújítások és építések. Az adminisztratív szolgáltatás területén az átlag feletti emelkedés 27\%-os lett, ezt föleg a lízingtársaságok fokozódó gép- és jármübeszerzései eredményezték.

A szállítás, raktározás - mint a harmadik nagyobb részarányú terület - beruházásainak volumene viszont visszafogottabban, 7,4\%-kal nőtt. Itt a régebb óta folyó infrastruktúraberuházások (út-, autópálya-, kerékpárút- és vasútépítések) említhetők. A közúti fuvarozó vállalkozások szintén növelték beruházásaikat. 


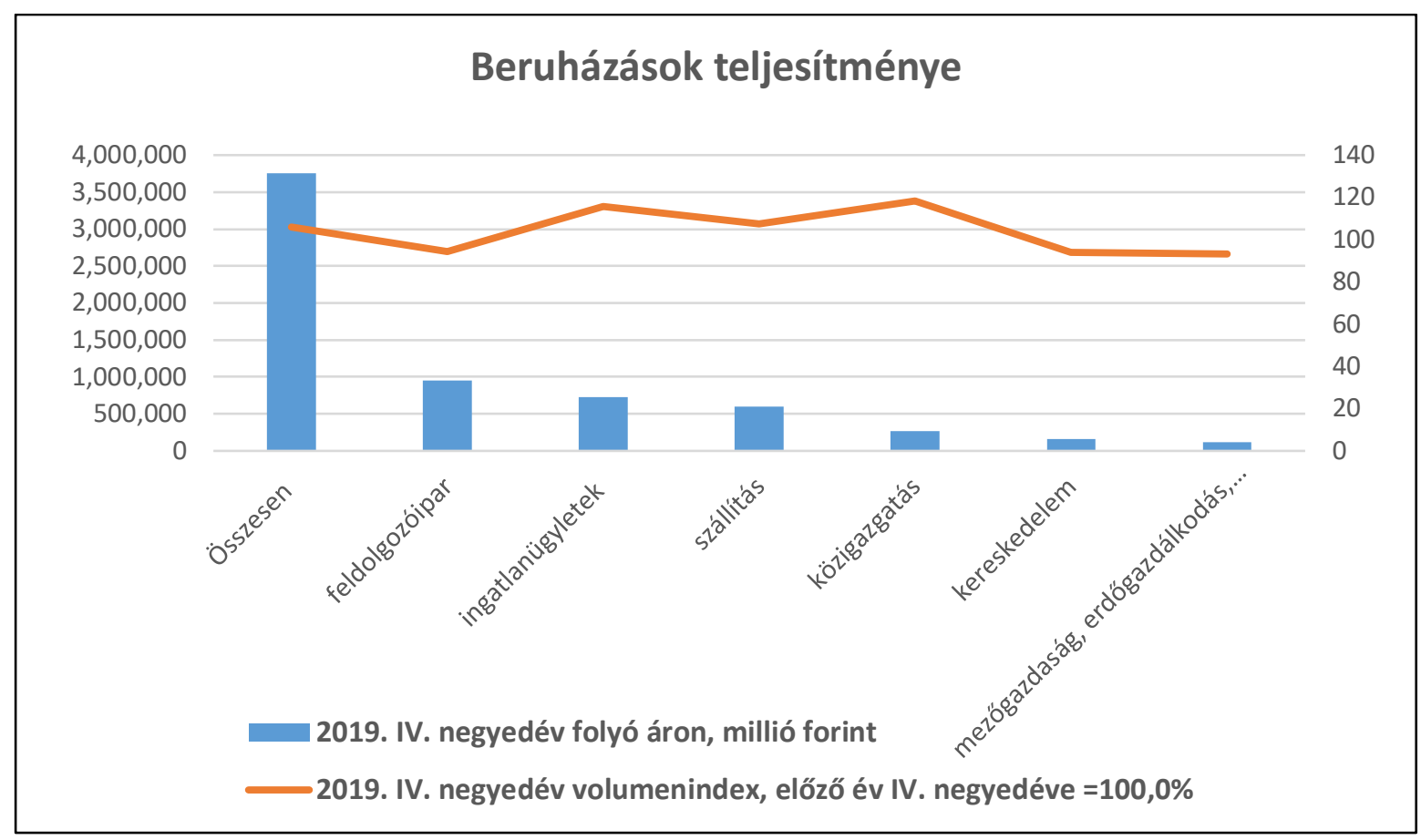

Forrás: KSH, saját szerkesztés

A közigazgatás, védelem, kötelező társadalombiztosítás területén a központi közigazgatási szervek fejlesztettek elsősorban, és 18\%-kal nőttek itt a beruházások. A sporttal és a kultúrával kapcsolatos projektek is $14 \%$-kal növelték a beruházásokat. A víz- és hulladék-gazdálkodás területén - a részben uniós forrás-finanszírozás eredményeként - a hulladékkezelő projektek, és a regionális közmüszolgáltatók fejlesztései eredményeként a beruházások volumene 7,2\%kal emelkedett. Az oktatásban (1,2\%), a humán egészségügyi, szociális ellátásban $(4,3 \%)$ mérsékeltebb volt a beruházások bővülése.

Az ágazati termelési sorrendben a hatodiknak számító kereskedelem, gépjárműjavítás a korábbi negyedévekkel szemben most már nem növelték a beruházásaik ütemét, sőt az visszaesett, 5,9\%-os a volumenváltozás. Ezt alapvetően az élelmiszer-kereskedelemi nemzetközi üzletláncok korábbi magas bázishoz képest csökkenő volumenű beruházási tevékenysége okozta.

\section{A 2019. utáni fejlődés}

2020 elején még úgy láttuk, hogy a magyar gazdaság 2019-ben kissé lassuló bővülése folytatódhat, annak ellenére, hogy a tavalyi év végére az építőipar kiugró növekedése visszaesett, és az ipar növekedési várakozásai is jócskán gyengültek. Az egyensúly további romlására utalt, hogy gyorsult a fogyasztói áremelkedés üteme, tovább gyengült a forint. Ezzel 
együtt a vállalatok és a háztartások körében az eddigi optimizmus csökkent, részben a külső gazdaság lassulását is okozó kockázati tényezők - Brexit, világgazdasági helyzet érezhető romlása, így a külkereskedelmi partnereink növekedésének lassulása - részben a változatlan versenyképességi problémákkal összefüggő hazai munkaerő-piaci anomáliáink miatt.

A 2020 márciusára kialakult világgazdasági helyzet azonban alapjaiban befolyásolja az eddig pozitívnak ítélhető felzárkózási folyamatunkat. Egyértelmüvé vált a komoly gazdasági visszaesés folyamata és teljességgel bizonytalanná az, hogy a koronavírus miatti, az egész világra kiterjedő járvány milyen hatásokkal jár a magyar gazdaságra nézve. A hazánkat érintő rövid- és hosszabb távú hatások valós mértéke még nem látható.

A 2020. március végéig ismertté vált tények alapján kíséreljük megbecsülni, hogy milyen lefutásai lehetnek a magyar gazdaság számára a koronavírus okozta válságnak.

Elöljáróban fontos hangsúlyozni, hogy most nem a pénzügyi szektor „fertőződöttsége” okoz világméretű járványt. A globalizált gazdaság folyamatai nagyjából rendben folytak, és most a valóban jól müködő rendszerek és ágazatok, vállalkozások kerültek/kerülnek lehetetlen helyzetbe, amely akár eddigi kiemelkedő tevékenységük ellenére csődjüket is okozhatja. Ezzel pedig hazánkban is százezreket foszt meg munkájuktól, a családok nagy részének okoz komoly megélhetési nehézségeket.

\section{Növekedés helyett visszaesés}

A nemzetközi gazdasági szervezetek jelenleg a globális GDP 1,9 százalékos csökkenését, ezen belül például az amerikai gazdaság 3,3 százalékos, az eurózóna 4,2 százalékos visszaesését valószínüsítik. A kínai gazdaság az első negyedévi zuhanás után lassan fog élénkülni, de éves szinten már 2 százalékkal is nőhet. Az EKB elnöke pedig az eurózónában 5\%-os visszaesésről beszél. A nemzetközi prognózisokban 2020 második negyedévében súlyos visszaesést, majd a második félévben már - igen nagy optimizmussal - emelkedést feltételeznek.

A gazdaságirányítás korábbi terveiben az szerepelt, hogy a magyar GDP 2019 évi 4,9\%-os bővülése 2020-ban 1,5 - 2 százalékponttal csökken. Az építőipari termelés jelentős, az ipari termelés mérsékeltebb visszaesése, valamint a beruházások számottevő gyengülése mellett a jövedelmi viszonyok romlása okozta fogyasztás csökkenéssel is számolhattunk. Az ipari bizalmi index és a magyar növekedést is befolyásoló EU konjunktúra-indexek, köztük az IFO üzleti index is már az első negyedévben egyértelmü gyengülésre-visszaesésre utaltak. 
Számítani kellett arra, hogy az állóeszköz-felhalmozás 2017 óta tartó 18-16\%-os volumenbővülése 2020-ban jelentősen lelassul 4\% körülire. A folyó fizetési mérleg 2019-es hiányát a beáramló külföldi működőtőke eddig még kompenzálta, és ezt vártuk 2020-ban is, egy - a korábbi 5 md euró feletti együttes mérleg helyett - 2,5 milliárd körüli mértékben. Feltételeztük azt is, hogy a világgazdaság és európai partnereink gazdasági visszaesése számottevően hat külkereskedelmi folyamatainkra és a forint árfolyamára is. A külkereskedelmi aktívumunk meghatározója pedig, hogy mind az export, mind az import az elmúlt években is folyamatosan csökkenő emelkedése 2020-ban további néhány százalékponttal visszaesik. Az EUtámogatások beruházás-serkentő hatása megszünik, és emellett a háztartások vásárló ereje is csak lassabban emelkedik majd.

A járvány hazai megjelenése óta komoly mértékben leromlottak a gazdasági kilátásaink. A járvány nagysága és vége nagyon bizonytalan, ezért a gazdasági romlás nagyobb is lehet, már ez évi 5-7\%-os visszaesést sem tartanak kizártnak az elemzők.

A feltételezett növekedési pályában a 2020 negyedik negyedévi visszaesés mértéke akár 7-8 \% is lehet. Egyértelmü, hogy a fiskális és monetáris folyamatainkat alapvetően átírja az államháztartás gazdasági válság megoldására fordítandó forrás-átcsoportosítása és felhasználása, valamint a forint árfolyam gyengülése és az infláció várható meglódulása.

GDP volumenváltozás*

(előző év azonos időszakához, \%)

\begin{tabular}{|c|c|c|c|c|c|c|c|}
\hline \multirow{2}{*}{$\begin{array}{c}\text { negyedév/ } \\
\text { év }\end{array}$} & \multicolumn{3}{|c|}{ Az elöző válság évei } & \multicolumn{3}{c|}{ A korona-vírus járvány ideje } \\
\cline { 2 - 9 } & 2008. & 2009. & 2010. & 2019. & 2020. & $\mathbf{2 0 2 0 .}$ & $\mathbf{2 0 2 1 .}$ \\
\hline I. & \multicolumn{4}{|c|}{ tény } & $\begin{array}{c}\text { februári } \\
\text { előrejelzés }\end{array}$ & márciusi becslés \\
\hline II. & 102,2 & 92,9 & 99,5 & 105,3 & 104,2 & $\mathbf{1 0 2 , 6}$ & $\mathbf{9 3 , 3}$ \\
\hline III. & 102,6 & 92,1 & 100,4 & 104,9 & 103,6 & $\mathbf{9 6 , 5}$ & $\mathbf{9 6 , 5}$ \\
\hline IV. & 97,9 & 95,6 & 101,4 & 104,5 & 102,8 & $\mathbf{9 2 , 7}$ & $\mathbf{1 0 2 , 5}$ \\
\hline ÉvV & 101,1 & 93,3 & 100,7 & 104,9 & 103,2 & $\mathbf{9 6 , 3}$ & $\mathbf{9 8 , 0}$ \\
\hline változás \% & - & $-6,7$ & 0,7 & - & 3,2 & $\mathbf{- 3 , 7}$ & $\mathbf{- 2 , 0}$ \\
\hline
\end{tabular}

* Forrás: KSH és a szerzö becslése a válság várható lefolyása alapján, 2020. márciusban 
2020 első negyedévének végére már érezhetővé vált a gazdaság pénzügyi mutatóinak számottevő romlása. A monetáris és fiskális helyzetünk bizonytalanságai a válság legszembetűnőbb jellemzője lesz. A válság kedvezőtlen hatásainak leküzdése a kiadások jelentős átcsoportosításával a GDP akár egyötödét elérő nagyságú is lehet. A 2020-ra tervezett, akár 1\% körülire csökkenő államháztartási hiány 3\% fölé emelkedhet. Az EU ez évben eltekint attól, hogy a tagországok betartsák a fiskális kritériumokat. Ez azt jelenti, hogy az ez évre tervezett 367 milliárdos hiányt akár további 900-1000 milliárd Ft-tal túl is lehet lépni, a várható rendkívüli EU-s támogatás felhasználásán túl.

Külső segítséget jelent, hogy az Európai Unió 100 milliárd eurót biztosít a munkahelyek és vállalkozások fenntartására. Ezt a támogatást a tagállamok kedvező feltételekkel nyújtott kölcsönök formájában vehetik majd igénybe. A Bizottság által "szolidaritási pénzügyi eszköznek" nevezett csomag célja, hogy a munkavállalók megélhetése ne kerüljön veszélybe, a vállalkozásokban alkalmazottak rövidített munkaidőben dolgozhassanak és továbbra is fizetni tudják bérleti díjaikat, számláikat, mindezzel is elősegítve a gazdaság stabilizálását. Minden tagállamnak lehetősége lesz arra, hogy pénzügyi garancia ellenében igénybe vegye a támogatást.

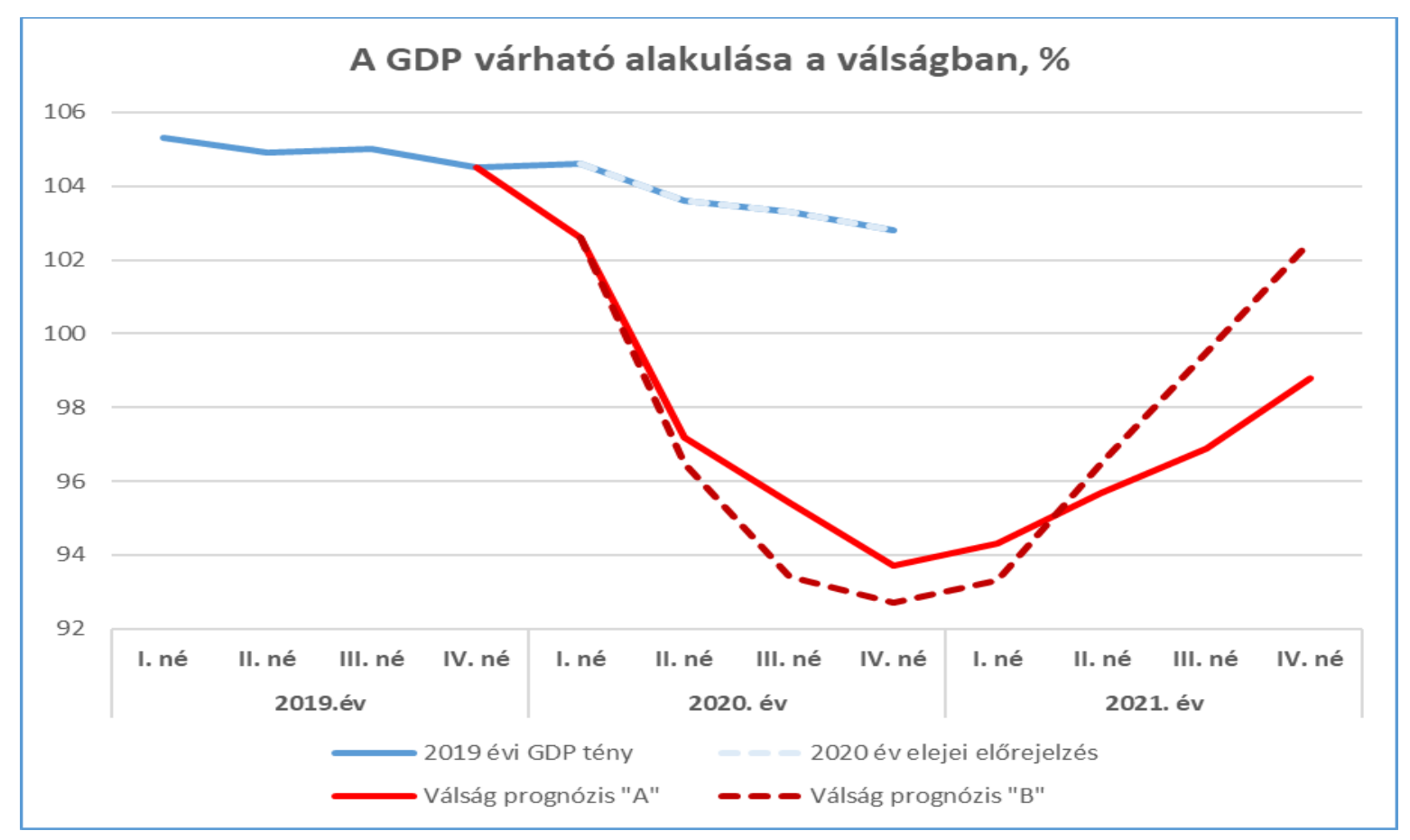

Forrás: KSH és a szerző becslése 
A külföldi jegybankok már a járvány kirobbanása előtt recessziót feltételezve megszüntették gazdaságukat segítendő a monetáris szigorítást. Ezzel egyúttal csökkent az MNB-re nehezedő kamatemelési nyomás, így a monetáris szigorítás elmaradásának természetes következménye lett a forint folyamatos gyengülése. A magyar és külföldi valuták közötti kamateltérések nagy volumenű shortolásra adtak lehetőséget, amely végül is a forint további gyengüléséhez vezetett, majd inflációt is gerjesztett. A válság bekövetkeztével a 2019. évi 325 forintos átlagos euróárfolyam 2020 végére 350-360 fölé is romolhat. A gyengülő hazai fizetőeszköz hátrányosan fogja érinteni a magyarországi bérszínvonalat is. Az erősödő euróval-számolva viszont egyre kedvezőbb helyzetbe kerülhetnek a külföldi cégek a bérezést és a foglalkoztatási terheket tekintve. Az idei infláció alakulása kérdéses.

2019-ben a bankszféra nagy nyereséget termelt. A vállalati szféra 90 napon túli és a nemteljesítő hiteleinek aránya az elmúlt évekbeli csökkenés eredményeként már 2\%-hoz közeli mértékre csökkent. A bankok gazdálkodásának kamateredménye, müködési bevétele és általános eredménye is folyamatosan javult az elmúlt években. A Kormány által elrendelt - az egyik legkorábbi válságkezelő intézkedést jelentő - hitel visszafizetési moratórium tulajdonképpen csak hónapokkal eltolt kamatbevételt jelent számukra. A helyzet konszolidálódását követően a vállalati és lakossági hitelállomány eddigi dinamikus emelkedése folytatódni fog. A pénzügyi szektorban a kamatokra és tőketörlesztésre elöírt moratórium átmenetileg rontja a bankok helyzetét, likviditását, de ez jóval kisebb kárt jelent, mint az életképes cégek csődje, és a háztartások pénzügyi ellehetetlenülése. Átmenetileg lelassul a pénzügyi szféra növekedése, de feltehetően a leggyorsabban fog magához térni a válságból a gazdasági ágazatok közül.

Az MNB hosszú ideje folytatott laza monetáris politikája miatt nem igen tudna további lazítást végrehajtani, pedig a csökkenő teljesítményű gazdaság lazítást igényelne. A növekvő infláció okán viszont az árstabilitás követelménye miatt szigorításra lenne szükség.

Az elmúlt évek jelentős fogyasztás-bővülése az előrejelzések szerint 2020-tól - a lassuló növekedéssel együtt már kissé mérséklődött volna - a válság nélkül is. A fogyasztást fékezik a magas lakásépítési-, karbantartási költségek, a lakásbérlés magas szintje és a megindult inflációs folyamat is.

A válságnak számos, az inflációt befolyásoló hatása van, ezért várható alakulása is nehezen becsülhető. A fogyasztói piac nagy részénél - élelmiszereknél, ázsiai import iparcikkeknél - a hiányhelyzet és az importverseny csökkenése vagy megszünése okozhat áremelkedést, más cikkeknél viszont a világpiaci áresések (olaj, energia) jellemzők. Egyébként pedig a járvány 
időszakában a fogyasztásnak a szokásostól nagymértékben eltérő alakulása torzíthatja a statisztikailag számított inflációt.

\section{Jövedelem-szükülés}

Fontos áttekinteni, hogy milyen eredményeket ért el 2020 elejére, azaz milyen szintről esik vissza a vállalati, a háztartási és a közösségi szektor. A fogyasztás szükülés mértékét, az eddigi növekedés visszaesésének hatásait csak sejteni lehet. Nyilvánvaló, hogy nagyon eltérő mértékben érzik meg a különböző jövedelmü családok a válságot.

A háztartások helyzetét és kilátásait a foglalkoztatási viszonyok alakulása alapvetően meghatározza. A járványügyi veszélyhelyzet következtében a romló vállalati gazdálkodással összefüggésben egyértelmüen romlanak a foglalkoztatottsági mutatók, és a dolgozók jelentős körében lecsökken a havi jövedelem. A gazdálkodó szervezetek körében általánossá válik, hogy akár 50\%-kal is csökkentik dolgozóik fizetését.

2019. év végén a regisztrált munkanélküliek mintegy 15\%-a 25 éven aluli fiatal volt, kétharmaduk első munkahelyét kereste, de esetenként nem sok eredménnyel. A munkanélküliek egyharmadának nincs szakképzettsége. Az álláskeresők egynegyede az elhelyezkedés szempontjából az egyik legkiszolgáltatottabb korcsoportba tartozó 55 éven felüli. A munkanélküliek gazdaságilag aktív népességhez viszonyított aránya öt megyében is meghaladta, illetve elérte az országos átlag másfélszeresét: Somogy megyében 9,7\%-ot, Szabolcs-Szatmár-Bereg megyében 9,3\%-ot, Baranya megyében 8\%-ot, Hajdú-Bihar megyében 7,9\%-ot, Jász-Nagykun-Szolnok megyében szintén 7,9\%-ot.

Jelentős szélsőségek vannak a kereseti-jövedelmi viszonyokban. A bruttó átlagbér 2019-ben a pénzügyi, biztosítási tevékenység gazdasági ágban 656.100,- Ft, míg a szálláshely-szolgáltatás, vendéglátás területén csupán 238.100,- Ft volt. A becslések szerint az átlagbérnél mintegy húsz százalékkal lehet alacsonyabb a medián bér Magyarországon. Azaz a kedvezmények nélküli 268 ezer Ft-os novemberi átlagkereset helyett 215 ezer $\mathrm{Ft}$ a medián kereset, az adókedvezményeket is figyelembe véve pedig csak 221 ezer Ft.

A felső jövedelmi tizedek javuló helyzetére utal, hogy az Államadósság Kezelő Központ adatai szerint 2019. végére a lakosság birtokában már több mint 9 ezer milliárd forint értékü állampapír volt, ez az állomány év elejétôl 20\%-kal növekedett. Az állampapír plusz nyár elejétől elérhető magasabb hozama megnövelte és át is strukturálta a megtakarításokat, ezzel 
persze fékezve az expanziót. A lakosság betétállománya meghaladta a kilenc és fél ezer milliárd forintot, hitelállománya pedig több mint 7 ezer milliárd forintot tett ki.

Nagymértékben növekedtek a lakosság által befizetett adók összegei is. A háztartások egy év alatt mintegy $10 \%$-kal több jövedelem típusú és 13\%-kal több fogyasztáshoz kapcsolt adót fizettek be. Az Áfa bevételek mintegy 16\%-kal, a jövedéki adó bevételek 6\%-kal lettek magasabbak, mint az előzó évben.

\section{A vállalati gazdálkodás bizonytalansága}

2019. végére a konjunktúra jelentések szerint a vállalati gazdálkodás mutatói az üzleti várakozások visszaesése ellenére sem romlottak. Az ipari termelés összességében szinten maradt. Az építőipar termelése azonban csökkent, az építőipar szerződésállománya év végén az egy évvel azelőttinél már jóval alacsonyabb volt.

A 2019-es év egészét tekintve a foglalkoztatottak átlagos létszáma 4 millió 512 ezer volt, a foglalkoztatási ráta a 15-64 évesek körében 70,1 százalékos volt, a munkanélküliség 2019 utolsó negyedévére 3,3\%-ra csökkent. Ez az EU egyik legkedvezőbb mutatója, és a közmunkásokkal együtt számított $6 \%$ alatti ráta is jobb az EU átlagánál. A munkaerőpiacon azonban változatlan maradt a strukturális feszültség. A tartós munkaerő-piaci nehézségeknek a hatása érezhető volt a gyengülő gazdasági konjunktúrában.

A járvány mélysége és időtartama teljesen bizonytalan. A lakosság mozgásának szigorú korlátozása szükségképpen a gazdasági folyamatok visszaesésével, és így remélhetőleg rövid ideig tartó recesszióval jár. A globális termelői folyamatok és a kereslet visszaesésével komoly mértékü bizonytalanság határozza meg a kilátásokat.

A bekövetkezett válságban a foglalkoztatottak számának csökkenése időszakosan 350-400 ezer fő is lehet, és szinte valamennyi ágazatot érinteni fogja. A szakképzett munkaerőt foglalkoztató, normál körülmények között piacképes termékgyártó, illetve szolgáltató cégek egy része most különböző keresetcsökkentő technikákkal igyekszik megtartani a munkaerőt, míg a nem elég tőkeerős szervezetek elbocsátják dolgozóikat. Elsősorban a kkv-k alkalmazottai, és az önfoglalkoztatók veszélyeztetettek.

Az eddigi 160 ezer fős munkanélküliség (3,4\%-os ráta) átmenetileg nagyon megemelkedik, akár $8 \%$ felettire. További probléma, hogy a mozgóbérek összeszükülnek, általános eszközként használják a cégek a fizetés nélküli szabadságot, a rendelkezésre állási díj fizetését. A minimálbér-emelés hatását a cégek csökkentett munkaidővel fogják elkerülni. A bruttó 
keresetek átmenetileg a gazdaság jelentős részében nominálisan is vissza fognak esni, és csak a helyzet konszolidálódásával állhat helyre a bérszínvonal.

A márciustól hazánkban is jelenlévő koronavírus okozta válság bekövetkeztével a kormány jelentős engedmények biztosításával-teszi lehetővé az átmeneti adó- és járulék mentességet a foglalkoztatottak bérfizetéséhez, a munkaerő lehetséges megtartásához.

\section{A válság elsö hatásai}

A válság első megrendítő hatása a munkaerö-piaci sokk volt. Be kellett zárni munkahelyeket, ágazatok tevékenysége szünt meg részben vagy egészben, mint pl. az idegenforgalom és a szolgáltatások nagy része. A 4,5 millió foglalkoztatott akár 8-10\%-ának teljesen megszünt a munkahelye. További 40-50\%-nak pedig korlátozott volt, azaz néhány órára szükül, otthoni munkavégzéssé vált a tevékenysége. A veszélyhelyzet szomorú következménye lett az akár hosszabb idöre is jelentősen csökkenő munkavégzés. Az idegenforgalomban müködő cégek (szállodák, éttermek), a szolgáltató tevékenységeket végző szervezetek (kultúra, oktatás, közigazgatás stb.) egyértelmüen a foglalkoztatottak elbocsájtására, illetve a tevékenységvégzés módjának a megváltoztatására kényszerültek.

Az ágazatok létszáma és súlya a GDP-ben

\begin{tabular}{|l|c|c|}
\hline \multicolumn{1}{|c|}{ ágazat } & $\begin{array}{c}\text { GDP } \\
\text { ezer fö } \\
\text { súlyarány, } \\
\text { \% }\end{array}$ \\
\hline Mezögazdaság, erdögazdálkodás, halászat & $\mathbf{2 1 0 , 7}$ & $\mathbf{4 , 2}$ \\
\hline Bányászat, köfejtés & $\mathbf{1 1 , 5}$ & $\mathbf{0 , 3}$ \\
\hline Feldolgozó- ipar & $\mathbf{9 9 6 , 6}$ & $\mathbf{2 2 , 1}$ \\
\hline Villamos- energia-, gáz-, gözellátás, légkondicionálás & $\mathbf{3 4 , 5}$ & $\mathbf{1 , 5}$ \\
\hline Vízellátás; szennyvíz gyüjtése, kezelése, hulladék-gazdálkodás, & $\mathbf{5 8 , 2}$ & $\mathbf{0 , 9}$ \\
\hline Szennyezódés-mentesítés & $\mathbf{3 4 3 , 3}$ & $\mathbf{5 , 3}$ \\
\hline Építőipar & $\mathbf{5 7 0 , 0}$ & $\mathbf{1 1 , 0}$ \\
\hline Kereskedelem, gépjármüjavítás & $\mathbf{3 0 3 , 3}$ & $\mathbf{6 , 1}$ \\
\hline Szállítás, raktározás & $\mathbf{1 8 6 , 8}$ & $\mathbf{1 , 9}$ \\
\hline Szálláshely-szolgáltatás, vendéglátás & $\mathbf{1 3 2 , 5}$ & $\mathbf{5 , 0}$ \\
\hline Információ kommunikáció & $\mathbf{7 6 , 4}$ & $\mathbf{3 , 5}$ \\
\hline Pénzügyi, biztosítási tevékenység & $\mathbf{2 4 , 7}$ & $\mathbf{7 , 9}$ \\
\hline Ingatlan- ügyletek & $\mathbf{1 6 8 , 4}$ & $\mathbf{6 , 2}$ \\
\hline Szakmai, tudományos, müszaki tevékenység & $\mathbf{1 3 9 , 8}$ & $\mathbf{4 , 0}$ \\
\hline Adminisztratív és szolgáltatást támogató tevékenység & $\mathbf{4 0 7 , 2}$ & $\mathbf{8 , 0}$ \\
\hline Közigazgatás, védelem; kötelezó társadalombiztosítás & $\mathbf{3 4 5 , 5}$ & $\mathbf{4 , 5}$ \\
\hline Oktatás & $\mathbf{3 1 8 , 2}$ & $\mathbf{4 , 6}$ \\
\hline Humán-egészség- ügyi, szociális ellátás & $\mathbf{8 0 , 1}$ & $\mathbf{1 , 5}$ \\
\hline Müvészet, szórakoztatás, szabad idő & $\mathbf{1 0 4 , 4}$ & $\mathbf{1 , 4}$ \\
\hline Egyéb tevékenység & $\mathbf{4 5 1 2 , 1}$ & $\mathbf{1 0 0 , 0}$ \\
\hline Összesen &
\end{tabular}

Forrás: $K S H$ 
A Pénzügyminisztérium a veszélyhelyzet elrendelése óta egyre komolyabb csökkenést valószínüsít. Bizonyossá vált, hogy a foglalkoztatottság korlátozása is hosszabb időszakot fog érinteni. A gazdasági teljesítmény becslésének egyik kiindulópontja az ágazatok létszámcsökkenésének hatásvizsgálata. Végig kell nézni, hogy milyen mértékben és milyen multiplikatív módon hatott a foglalkoztatottság csökkenése egy-egy ágazat teljesítményére.

A válság az idegenforgalom és a szolgáltató szektor azonnali leállását és a kapcsolódó tevékenységekre kiterjedő beszükülését okozta. Elhúzódása a beruházási volumen legalább 810\%-os, a foglalkoztatottság akár 10\%-os csökkenését generálta a szinte valamennyi ágazatra kiterjedő termelés-csökkenés/leállás következtében. A kereskedelem nagy részénél a kijárási korlátozás következtében bezártak az üzletek. Az ipari tevékenységeknél a kereslethiány okozott termelés csökkenést, az autóipar szinte teljesen leállította a termelést. A globális ellátási láncokba integrálódott vállalatoknál időszakos leállások történtek és ez a folyamat begyürüzött a kkv-szektor tevékenységeibe is. Az ipari ágazat akár 10\%-os visszaesése is elképzelhető. A nemzetközi szállításokban a leálló cégekhez történő szállítások megszünése miatt lesz komolyabb csökkenés. A mezőgazdaságban az idény munkaerőhiány okozott jelentős termelés csökkenést, ez akár 400 md Ft is lehet.

A kijárási korlátozások, az otthoni munka és oktatás „eredményeként” a telekommunikációs szektorban történt bővülés. Ugyancsak növekedett a teljesítmény az egészségügy és a közigazgatás egyes szektoraiban a járvány leküzdésével összefüggő tevékenységek iránti fokozódó kereslet miatt.

A kormányzat a 2020. évi költségvetés radikális átalakítását hajtotta végre. Ez azért vált szükségessé, hogy forrásokat lehessen adni a csődhelyzetbe kerülő, átmeneti munkaerő gondokkal küszködő vállalatoknak, a gazdasági ellehetetlenülés és a munkanélküliség minimalizálása érdekében. Jelen prognózisunkban foglaltak azonban csupán a válság okozta folyamatok lehetséges - inkább optimistának ítélhető - számszerű lefutását jelzik, és tudjuk, hogy ettől eltérő is lehet majd a valóság.

Nyilvánvaló, hogy a következő hónapokban, negyedévekben a növekedés szükségszerü visszaesésével, a munkanélküliség várható nagyobb mértékű növekedésével a költségvetés súlypontjai áthelyeződnek, nagymértékü forrásokat igényel majd a vállalati gazdálkodás fenntartása, illetve újbóli beindítása. A koronavírus-járvány leküzdése során a munkaerőpiac átalakításában, a béralakulás kedvező változásaiban eddig elért eredmények megőrzése is 
nehézségekbe fog ütközni. Mivel a járvány lefolyását sem ismerjük, azt sem igen lehet pontosan megbecsülni, hogy mekkora és milyen szerkezetü lesz a visszaesés és így honnan kell majd újra kezdeni az „építkezést.” Ahhoz, hogy minél kevesebb negatív hatással „vészeljük át” ezt a gazdasági-társadalmi válságot, gyors és hatásos intézkedések kellenek. Reményeink szerint ezek az intézkedések folyamatosan segítik majd a társadalom és a gazdaság helyzetének javítását.

A 2020 márciusától kialakult világgazdasági helyzet azonban alapjaiban befolyásolta és a későbbiekben is meghatározza az eddig pozitívnak itélhetö felzárkózási folyamatunkat. Egyértelmüvé vált a komoly gazdasági visszaesés folyamata és teljességgel bizonytalanná az, hogy a koronavirus miatti, az egész világra kiterjedö járvány milyen hatásokkal jár a magyar gazdaságra nézve. A hazánkat érintö rövid-és hosszabb távú hatások valós mértéke még nem látható. A lapzártakor jelent meg a KSH 2020. második negyedéves GDP gyorsbecslése, amely alapján a nyers adatok szerint 13,6, a szezonálisan és naptárhatással kiigazított és kiegyensúlyozott adatok szerint 13,5\%-kal csökkent az elözö év azonos idöszakához viszonyítva. A járvány miatti rendkívüli helyzet hatására a legtöbb nemzetgazdasági ág termelése visszaesett, föleg a szolgáltatások és az ipar ágazataiban történö teljesítmény romlás következtében. A nemzetgazdaság teljesítménye az I. félévben 6,1\%-kal csökkent a nyers adatok szerint. és mindezek még az elmondottaknál is kedvezötlenebb helyzetet jeleznek. 


\section{Felhasznált irodalom}

1. Központi Statisztikai Hivatal - Gyorstájékoztatók, 2019, 2020

2. Magyar Nemzeti Bank - Inflációs jelentések, 2019, 2020

3. Policy Agenda - gazdasági tájékoztatók

\section{Adatforrások:}

KSH, MNB, PM, NFSZ, MÁK, OECD, Eurostat, IMF 